\title{
Diabetic Autonomic Neuropathy: Pathogenesis to Pharmacological Management
}

Navpreet Kaur, Lalit Kishore and Randhir Singh ${ }^{*}$

M.M. College of Pharmacy, M.M. University, Mullana-Ambala, Haryana 133207, India

*Corresponding author: Randhir Singh, M.M. College of Pharmacy, M.M. University, Mullana-Ambala, Haryana, India, Tel: +91-9896029234; E-mail: dahiya_rsd@rediffmail.com

Received: April 23, 2014, Accepted: June 27, 2014, Published: July 04, 2014

Copyright: $\odot 2014$ Singh R. This is an open-access article distributed under the terms of the Creative Commons Attribution License, which permits unrestricted use, distribution, and reproduction in any medium, provided the original author and source are credited.

\begin{abstract}
Diabetic autonomic neuropathy is a debilitating complication of diabetes which can cause heart disease, gastrointestinal symptoms, genitourinary disorders and metabolic diseases. Hyperglycemia induces glucose flux through the polyol pathway; excess/inappropriate activation of Protein Kinase C (PKC) isoforms; accumulation of Advanced Glycation End products (AGE's) and these pathways are associated with metabolic and/or redox state of the cell. Activation of these metabolic pathways leads to oxidative stress which is a mediator of hyperglycemia induced cell injury and is a unifying theme for all mechanisms of diabetic autonomic neuropathy. Glycemic control can slow the onset of diabetic autonomic neuropathy and may reverse it. Pharmacologic and non-pharmacologic therapies are available to treat various symptoms of diabetic autonomic neuropathy. This review focuses on the pathology, animal models and therapeutic approaches available for the management of diabetic autonomic neuropathy.
\end{abstract}

Keywords: Diabetic autonomic neuropathy; Hyperglycemia; Oxidative stress

\section{Introduction}

Neuropathy is a long term complication of both Type 1 (T1DM) and Type 2 Diabetes (T2DM) [1,2]. In recent years, considerable progress has been made toward understanding the biochemical mechanisms leading to diabetic neuropathy. Typical symptoms of diabetic neuropathy include pain, numbness, tingling, weakness, and difficulties in balance associated with substantial morbidities like depression, susceptibility to foot or ankle fractures, ulceration and lower-limb amputation Diabetic neuropathy may be categorized in two general headings: focal and diffuse neuropathies. The focal neuropathies are less common, usually acute in onset and self-limited. The diffuse neuropathies, i.e., Distal Symmetrical Sensorimotor Polyneuropathy (DPN) and Diabetic Autonomic Neuropathy (DAN) are common, usually chronic and progressive. DAN is the other form of diffuse diabetic neuropathy. It is manifested by dysfunction in one or more organ systems like, cardiovascular, gastrointestinal, ocular or genitourinary.

\section{Pathophysiology}

The metabolic hypotheses for diabetic complications include polyol pathway hyperactivity and its related myo-inositol deletion, increased diacylglycerol-protein kinase $\mathrm{C}$ cascade, oxidative stress, and nonenzymatic glycation [4]. Metabolic abnormalities cause functional alterations of neural cells and finally lead to structural alterations in nerve tissues. Vascular deficit-induced ischemia and hypoxia also cause functional and structural abnormalities in nerve tissues [5].

\section{Role of Polyol pathway in DAN}

Among all the metabolic pathways, the polyol pathway hypothesis has been considered as the leading metabolic contender for neuropathy. Multiple etiology of DAN leads to autoimmune damage and neurovascular insufficiency. Chronic hyperglycemia leads to activations of polyol pathway which in turn activates sorbitol and fructose accumulation and reduces sodium-potassium ATPase levels. This alter fatty acid metabolism and increase the accumulation of advanced glycated end products and oxidative stress. This pathway ultimately cause neuronal damage and decrease neuronal blood flow (Figure 1).

\section{Role of Protein kinase C pathway in DAN}

Elevated glucose level stimulates Diacylglycerol (DAG) which in turn activates Protein Kinase C (PKC). Activation of PKC reduces neuronal blood flow resulting in worsening of DAN. Upon activation of PKC, MAPKs (mitogen activated protein kinases) are activated which phosphorylate transcription factors and thus alter the balance of gene expression (Figure 2). Inhibition of PKC- $\beta$ reduces oxidative stress and normalizes blood flow and nerve conduction deficits in diabetic rats $[6,7]$.

\section{Role of AGE pathway in DAN}

Non-enzymatic protein glycation by glucose is a complex cascade of reactions yielding a heterogeneous class of compounds, collectively termed as AGEs [8]. AGEs disrupt the function of neurons in DAN by acting on cell surface specific receptors named RAGEs (Figure 3). AGEs activate Nicotinamide Adenine Dinucleotide Phosphate (NADPH) oxidase, Mitogen-Activated Protein Kinases (MAPK), stimulate cell division and activate various transcriptional factors like Nuclear Factor-Kappa B (NF- $\kappa \mathrm{B})$ to induce local inflammatory cascades, which execute diabetic vascular complications [9].

\section{Role of oxidative stress in DAN}

The balance between the rate of free radical generation and elimination is important, however, if there is a significant increase in radical generation, or a decrease in radical elimination from the cell, oxidative cellular stress ensues [10]. Increased production of Reactive 
Oxygen Species (ROS) induces oxidative stress in both type of diabetes [11]. Diabetic autonomic neuropathy involves alteration of metabolic pathways which in turn alters redox capacity of the cell. Furthermore these pathways also trigger damage through expression of inflammation proteins leading to impaired neural function, gradually heading to apoptosis of neurons, Schwann and glial cells of peripheral nervous system [12]. The disease arises from a combination of microvascular and neuronal deficits. Oxidative stress can contribute significantly to these deficits as a direct result of prolonged hyperglycemia [13].

Increased oxidative stress causes vascular endothelium damage and reduces nitric oxide availability. Excess nitric oxide production leads to the formation of peroxynitrite which causes nerve damage (Nitrosative stress). All these pathways in combination, results in reduced endoneural blood flow and nerve hypoxia leading to altered nerve function.

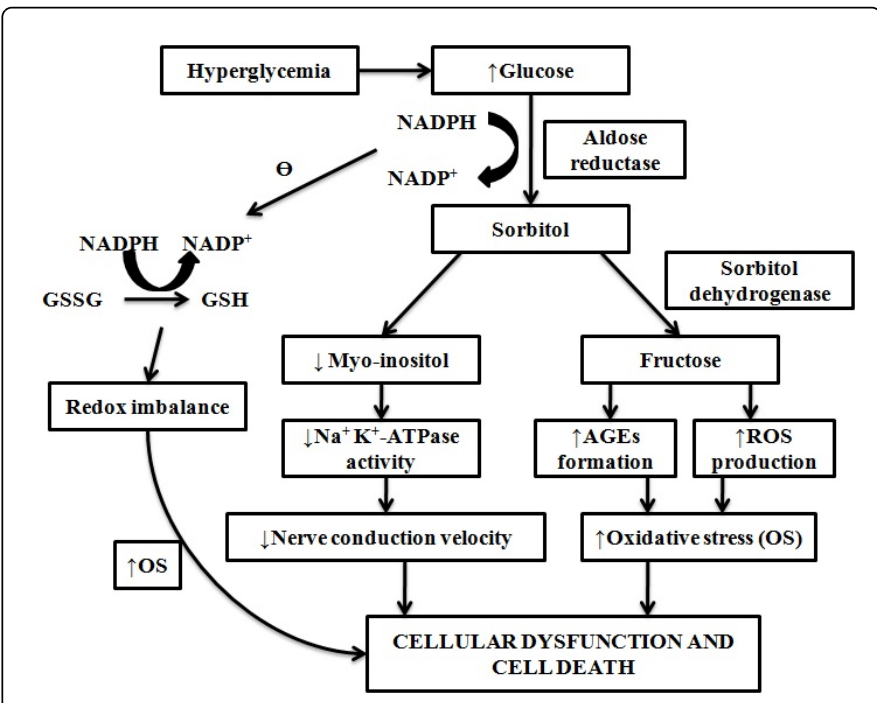

Figure 1: Polyol pathway: Chronic hyperglycemia leads to activations of polyol pathway which in turn activates sorbitol and fructose accumulation ultimately leading to increase oxidative stress and cell death. AGE advanced glycation end products, ROS reactive oxygen species, GSH glutathione, GR glutathione reductase, GSSG glutathione disulfide, NADPH nicotinamide adenine dinucleotide phosphate

\section{Clinical Manifestations}

DAN is often associated with DPN and can impair any sympathetic or parasympathetic autonomic function. It can affect any organ of the body, from the gastrointestinal system to the skin (Figure 4), and its appearance portends a marked increase in the mortality risk of diabetic patients. Although DAN is highly prevalent and associated with a markedly reduced quality of life and increased mortality, it is among the least recognized and most poorly understood complications of diabetes. Further, many of the clinical symptoms of DAN are common and may be due to factors other than diabetic neuropathy [14]. DAN can lead to life threatening conditions like silent myocardial infarction, ulceration, gangrene and nephropathy. DAN can be assessed by focusing on the symptoms or dysfunction of a specific organ system. Cardiac autonomic neuropathy is the most prominent factor because it leads to life threatening conditions.

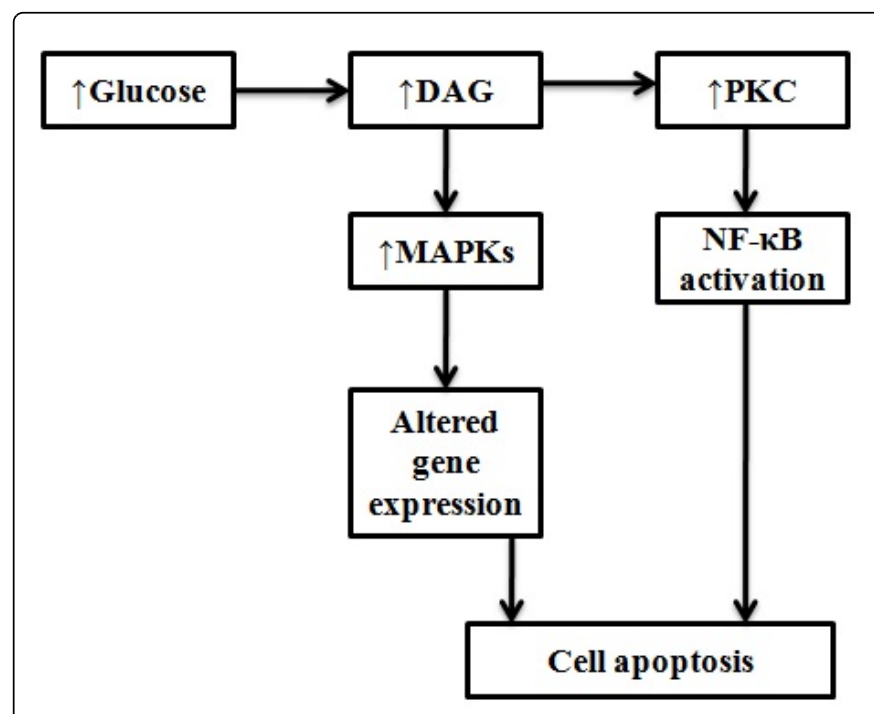

Figure 2: Mechanism of DAG-PKC activation: Hyperglycemia leads to activation of DAG and PKC which through increased MAPKs and activation of NF- $\mathrm{kB}$ results in cell death

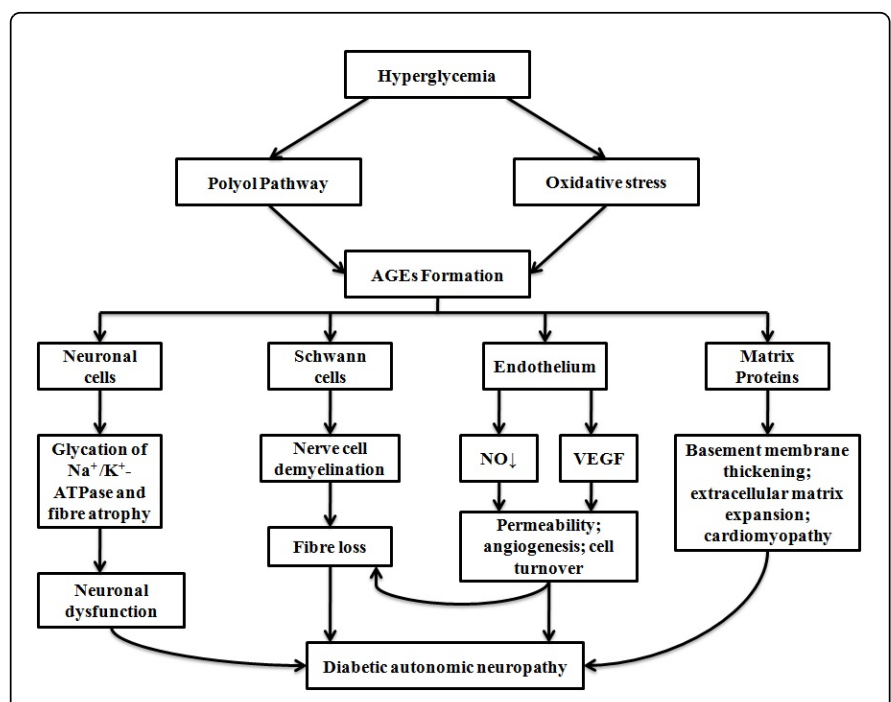

Figure 3: The mechanisms of AGE-mediated structural and functional alterations that lead to diabetic complications. Structural components like neuronal cells, Schwann cells, endothelium and matrix proteins (collagen, laminin, fibronectin) undergo nonenzymatic glycation leading to development of consequences of neuropathic changes.

\section{Animal Models for Diabetic Neuropathy}

Diabetic neuropathy has multifactorial etiology with many pathogenetic mechanisms. Diabetic animal models are employed to characterize these mechanisms. But these animal models are often without human correlation, so validation of these models is of particular importance. Animal models have been used to develop 
innovative therapies to prevent and treat diabetic neuropathy particularly to define the role of some molecules involved in pathophysiology.

\section{Type 1 diabetes models}

\section{Streptozotocin-induced model}

STZ is highly toxic for $\beta$ cells and is widely used to develop rodent models of type 1 diabetes. The development of STZ induced diabetic neuropathy is mainly dependant on the level and duration of hyperglycemia [15]. STZ enters the pancreatic $\beta$ cell via a glucose transporter GLUT2 and cause alkylation of Deoxyribonucleic Acid (DNA); furthermore STZ induces activation of polyadenosine diphosphate ribosylation and NO release. As a result of STZ action, pancreatic $\beta$ cells are destroyed by necrosis [16].

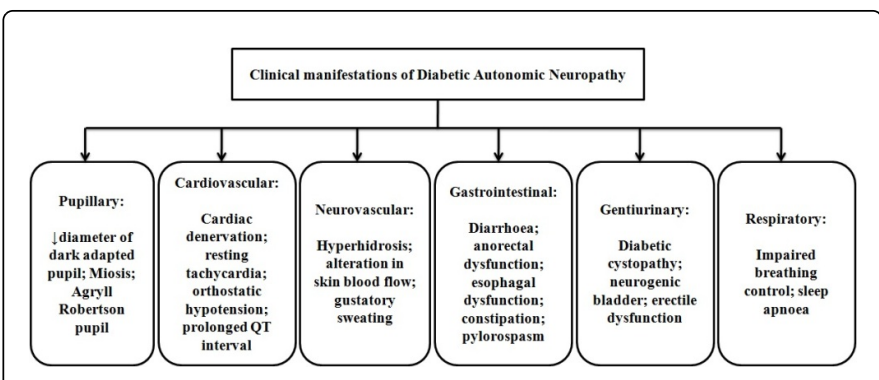

Figure 4: Clinical manifestation of diabetic autonomic neuropathy

Early symptoms of neuropathy observed in STZ diabetic rodents include impairment of endoneural blood flow, micro and macro vascular reactivities. In the first month of STZ induced neuropathy, slowing of Sensory Nerve Conduction Velocity (SNCV) and Motor Nerve Conduction Velocity (MNCV), hyperalgesia and allodynia are observed, then after 8-12 months of diabetes, sign of nerve degeneration, demyelination and loss of epidermal nerve fiber and hypoalgesia are manifestated diabetic rodents [17-19].

STZ induced diabetic mice have been proved to be better model than STZ diabetic rats because of their earlier maturity with a negligible weight loss. In first week of diabetes in STZ mice, vascular dysfunction develops followed by nerve demyelination in fourth week of diabetes with cutaneous C-fiber innervations in 6-7 weeks and decrease in MNCV and SNCV, hypoalgesia in 7-9 weeks [20,21].

\section{NOD mice}

NOD mice were developed in Japan by inbreeding Jcl:ICR strain. Development of $\beta$-cell destruction may mimic the pathophysiology of humans but very little work has been done study the complications in this model, the unpredictable age, late onset of diabetes and need of daily insulin therapy to survive for long periods are some of the factors associated with the model. However, the genetics of this model is also very complex $[22,23]$. Insulitis in NOD mice is developed at the age of 4-5 weeks (much earlier compared to humans) and has many differences from human insulitis. It begins with lymphocytes surrounding the islet perimeter and continues with an infiltration of the whole islet by an unusually large number of leukocytes (mainly $\mathrm{CD}^{+}$and $\mathrm{CD}^{+}{ }^{+} \mathrm{T}$-cells). Finally, after a period of subclinical $\beta$-cell destruction, overt diabetes is usually presented, when more than $90 \%$ of the pancreatic $\beta$-cells are destroyed (about at the age of 24-30 weeks) $[24,25]$. There have been relatively few studies of neuropathy in the NOD line; which indicated that tail-flick latency is unaltered in 2 weeks of diabetes in 12 week old NOD mice and thermal hypoalgesia is observed in 18 week old NOD mice [26,27]. Another study reported that diabetic NOD mice developed a significant time-dependent hyperalgesia which did not correlate with the hyperglycemia, but rather appeared very early alongside diabetes and significant at young age (8-10 weeks), which lasted up to 32 weeks [28].

\section{Bio-breeding/Worcester rat (BB/Wor-rat)}

The diabetes-prone BB rats were developed in 1970s from a colony of outbred Wistar rats in Bio-breeding Laboratories, Canada. Like NOD mouse, BB-rats also develop T-cell dependant autoimmune diabetes [29]. In this strain, hyperglycemia and insulinopenia develop at around 12 weeks of age [30]. In early phase, BB-rats show activation of the polyol pathway and reduced activity of $\mathrm{Na}^{+} / \mathrm{K}^{+}$-ATPase in nerves. In $\mathrm{BB} / \mathrm{Wor}$-rats, there is a greater decrease in MNCV than SNCV after 5 week of diabetes [31]. In addition, in BB/Wor-rats, the development of sympathetic autonomic neuropathy is characterized by neuroaxonal dystrophic changes of terminal axons [32].

\section{Type 2 diabetes models}

\section{Goto Kakizaki (GK) rats}

GK rats were developed by Japanese through repetitive breeding of Wistar rats. This model is characterized by glucose intolerance and defective insulin secretion. Defective glucose metabolism due to aberrant $\beta$ cell mass and insulin secretary defects leads to hyperglycemia in this model [33]. Diabetic complications similar to humans including, renal lesions, structural abnormalities in peripheral nerves and retinal abnormalities are observed in this animal model [34]. GK rats aging 2-9 months develop moderate hyperglycemia and exhibit a reduced MNCV with higher nerve fiber demyelination and axonal degeneration. Whereas, 18 months old GK rats exhibited impaired glucose tolerance, reduced $\mathrm{MNCV}$, fiber loss and atrophy. Levels of sorbitol rise leading to reduced $\mathrm{Na}+\mathrm{K}+\mathrm{ATP}$-ase activity along with reduced nerve myo-inositol levels and thermal hyperalgesia [35].

These rats were developed from diabetic Long Evans rats and are characterized by mild obesity. Diabetes develops late in this model and males are more likely to develop hyperglycemia earlier than females. Genome wide scans have reported susceptibility loci on chromosomes $1,7,14$ and also the $\mathrm{X}$ chromosome [36]. Interestingly, OLETF rats also carry a null allele for the cholecystokinin A receptor which may be involved in the regulation of food intake [37]. 4 months old OLETF rats show thermal hyperalgesia and up to 9 months there is no change in MNCV. OLETF rats develop nerve conduction deficit and peripheral nerve sorbitol pathway intermediate accumulation after an extended ( $\sim$ weeks $)$ feeding of sucrose to achieve severe hyperglycemia. All these changes are accompanied by activation of polyol pathway, sorbitol and fructose accumulation, reduced myoinositol in nerves which leads to further severity in neuropathy [38].

\section{ZDF rats}

Zucker Diabetic Fatty rats are developed from obese male Zucker rats that become diabetic and are selectively bred to create a stable new strain [39]. Diabetes in this strain is associated with impaired insulin secretion and peripheral glucose transporter function. These rats also 
are hyperinsulinemic, hyperlipidemic and hypertensive [40]. MNCV and SNCV were reduced in hyperglycemic 8 week old male ZDF rats compared with non-diabetic rats and MNCV remained reduced until 40 weeks old [40] and progressed to reduced sciatic endoneurial blood flow from 24-28 week [41].

\section{ob/ob mice}

ob/ob mice have no genetic mutations in leptin, obese, insulinresistant, hypertriglyceridemic, but normoglycemic [15]. ob/ob mice (approximately 11 weeks old) clearly develop sciatic motor nerve conduction velocity (MNCV) and hind-limb digital sensory nerve conduction velocity (SNCV) deficits, thermal hypoalgesia, tactile allodynia and an approximately $78 \%$ loss of intraepidermal nerve fibers. ob/ob mice also have increased sorbitol pathway activity in the sciatic nerve and increased nitrotyrosine and poly (ADP-ribose) immunofluorescence in the sciatic nerve, spinal cord and DRG cells [42]. The leptin-deficient ob/ob mouse is a new animal model of neuropathy of type 2 diabetes and obesity that develops both large and small sensory fiber peripheral diabetic neuropathy, offers a number of advantages over existing animal models and responds to pathogenic treatment [42].

\section{$\mathrm{db} / \mathrm{db}$ mouse}

$\mathrm{db} / \mathrm{db}$ mice have an autosomal recessive mutation in leptin receptor and are obese, hyper-insulinemic and hyperglycemic [16]. MNCV does not alter in earlier phase but as hyperglycemia progresses deficits develop. At the age of six months, there is progressive loss of large myelinated nerve fibers and significant accumulation of sorbitol and fructose in peripheral nerves [43].

All the above rat models and the neuropathic changes involved are summarized in Figure 5 and advantages and disadvantages of type 1 and 2 models is given in Table 1 .

\section{Treatment of diabetic autonomic neuropathy}

DAN can cause dysfunction of any or all parts of autonomic system. Intensive glycemic control can prevent the progression in DAN and delay all disorders associated with DAN. Drugs used in amelioration of DAN, their dosage regimen, side effects and the diagnostic tests for DAN have been discussed in Table 2. Treatment of DAN involves the amelioration of symptoms in the affected organ.

\section{Orthostatic hypotension}

The condition can be defined as a fall in $\mathrm{BP}(>20 \mathrm{~mm} \mathrm{Hg}$ for systolic or $>10 \mathrm{~mm} \mathrm{Hg}$ for diastolic) in response to postural change from supine to standing [44]. Patients with orthostatic hypotension typically present with lightheadedness and pre-syncopal symptoms. Symptoms such as dizziness, weakness, fatigue, visual blurring, and neck pain also may be due to orthostatic hypotension [45]. Two pathophysiological states cause orthostatic hypotension: autonomic insufficiency and intravascular volume depletion. Changes in plasma endothelin levels play an important role in BP regulation. The reduced plasma endothelin and nor-adrenaline response in diabetic patients with autonomic neuropathy contributes to development of orthostatic hypotension [46]. 9-fluorohydrocortisone and supplementary salt may benefit some patients with orthostatic hypotension. The randomized, double-blind controlled trial by Schoffer et al. [47] reported that fludrocortisone reduced supine and standing BP for systolic and diastolic components when compared to placebo. Clonidine, and $\alpha-2$ agonist, can treat a deficiency of $\alpha-2$ adrenergic receptor. However, in some patients with diabetic orthostatic hypotension, clonidine can actually increase blood pressure. Midodrine, an $\alpha-1$ adrenergic agonist, might be of benefit if non-pharmacologic measures, cortisone, salt supplementation and clonidine fail. The randomized, double-blind controlled trial by Figueroa et al. 2010 reported the mean change in supine and standing BP for systolic and diastolic components with midodrine and placebo, but no accompanying standard deviation, giving only the percentage change. Midodrine significantly improved the standing BP [48]. Octreotide may help some patients who experience particularly refractory orthostatic hypotension after eating [49] (Table 1).

\begin{tabular}{|c|c|c|c|}
\hline S.No. & Animal model & Advantage & Disadvantage \\
\hline 1. & $\begin{array}{l}\text { Type } \\
\text { diabetes }\end{array}$ & $\begin{array}{l}\text { Hyperglycemia persists } \\
\text { for several days } \\
\text { Spontaneous } \\
\text { destruction of } \beta \text {-cells } \\
\text { mimics the disease } \\
\text { pathology in humans } \\
\text { They are suited to study } \\
\text { diabetic autonomic } \\
\text { neuropathy }\end{array}$ & $\begin{array}{l}\text { Diabetes and obesity } \\
\text { symptoms overlaps } \\
\text { Limited availability and } \\
\text { expensive. Mortality due } \\
\text { to ketosis is high in animals } \\
\text { with brittle pancreas } \\
\text { (db/db, ZDF rats), and it } \\
\text { requires insulin in later } \\
\text { stage for survival } \\
\text { Drug-induced tissue toxicity }\end{array}$ \\
\hline 2. & $\begin{array}{l}\text { Type } \\
\text { diabetes }\end{array}$ & $\begin{array}{l}\text { These models mimic the } \\
\text { pathology of humans } \\
\text { It is likely to be as } \\
\text { complex and } \\
\text { heterogeneous as } \\
\text { human condition }\end{array}$ & Polyphagia and polyuria \\
\hline
\end{tabular}

Table 1: Advantages and disadvantages of type 1 and 2 animal models

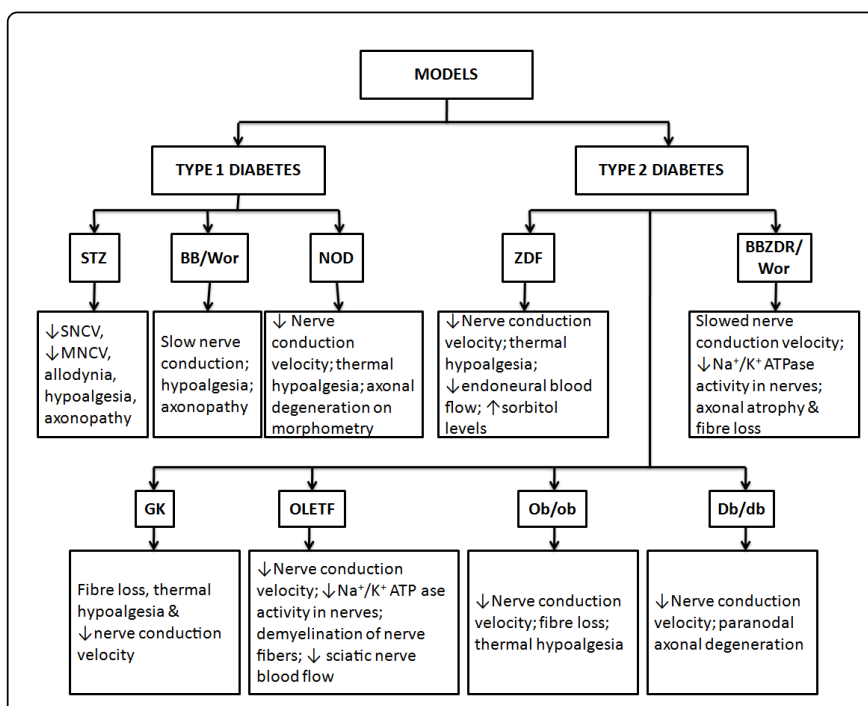

Figure 5: Animal models for diabetic autonomic neuropathy studies and the changes ocuuring in these models. STZ streptozotocin; $\mathrm{BB} /$ Wor Bio-breeding rat/Worcester rat; NOD non-obese diabetic rats; ZDF Zucker diabetic fatty rats; BBZDR/Wor Bio-breeding Zucker/Worcester rats; GK Goto Kakizaki rats; OLETF Otsuka Long-Evans Tokushima fatty rats. 
Citation: Kaur N, Kishore L, Singh R (2014) Diabetic Autonomic Neuropathy: Pathogenesis to Pharmacological Management. J Diabetes Metab 5: 402. doi:10.4172/2155-6156.1000402

Page 5 of 8

\begin{tabular}{|c|c|c|c|}
\hline Drug & Dosage & Diagnostic tests & Side effects \\
\hline \multicolumn{4}{|l|}{ Orthostatic hypotension } \\
\hline 9-a-fluoro hydrocortisone & $\begin{array}{l}0.1 \mathrm{mg} \text { titrated to } 0.5 \text { to } \\
2.0 \mathrm{mg} / \text { day }\end{array}$ & \multirow{9}{*}{$\begin{array}{l}\text { Measure B.P. by active standing test and } \\
\text { passive head up tilt testing (HUT) } \\
\text { Measure catecholamines }\end{array}$} & $\begin{array}{l}\text { Ankle edema, hypokalemia, congestive } \\
\text { heart failure }\end{array}$ \\
\hline Sympathomimetic agents & & & \\
\hline Ephedrine & $25-50 \mathrm{mg}$ t.i.d. & & \multirow[t]{4}{*}{ Sympathetic symptoms } \\
\hline Pseudoephedrine & $30-60$ mg t.i.d. & & \\
\hline Phenylpropanolamine & $12.5-25 \mathrm{mg}$ t.i.d. & & \\
\hline \multicolumn{2}{|l|}{ a-agonist } & & \\
\hline Midodrine (FDA approved) & 2.5-10 mg t.i.d. & & Anxiety and tachycardia \\
\hline Clonidine & $0.1-0.5 \mathrm{mg}$ & & Hypotension \\
\hline Octreotide & $0.1-0.5 \mu \mathrm{g} / \mathrm{kg} / \mathrm{day}$ & & Injection site pain and diarrhea \\
\hline \multicolumn{4}{|c|}{ Supplementary therapy like cox-inhibitor, caffeine etc. can be used } \\
\hline \multicolumn{4}{|l|}{ Diabetic Gastroparesis } \\
\hline Metoclopramide & 10 mg q.i.d. & \multirow{6}{*}{$\begin{array}{l}\text { Antroduodenal manometry } \\
\text { Breath test } \\
\text { Magnetic response imaging } \\
\text { Ultrasonography } \\
\text { Gastric emptying study } \\
\text { Electrogastrography }\end{array}$} & $\begin{array}{l}\text { Dystonic reactions, hyperprolactinemia, } \\
\text { extrapyramidal symptoms }\end{array}$ \\
\hline Erythromycin & $250 \mathrm{mg}$ t.i.d. & & $\begin{array}{l}\text { Nausea, vomiting, abdominal pain, antibiotic } \\
\text { resistance }\end{array}$ \\
\hline Domperidone & 10-20 mg t.i.d. & & Galactorrhea \\
\hline Bethanechol & 20 mg q.i.d. & & $\begin{array}{l}\text { Salivation, blurred vision, abdominal } \\
\text { cramps, bladder spasm }\end{array}$ \\
\hline Levosulpiride & 25 mg t.i.d. & & Galactorrhea \\
\hline Botulinum toxin type $A$ & --- & & --- \\
\hline Sepiapterin & 20 mg.kg b.w. & & --- \\
\hline \multicolumn{4}{|l|}{ Diabetic Diarrhea } \\
\hline Elementary diet & --- & \multirow{13}{*}{$\begin{array}{l}\text { Sensation tests of anus } \\
\text { Rectal examination of sphincter muscles } \\
\text { Endoscopy examination of GIT } \\
72 \mathrm{hr} \text { stool examination-tests for pancreatic } \\
\text { enzyme function }\end{array}$} & --- \\
\hline Pancreatic extracts & --- & & ---- \\
\hline Antidiarrheal agents & --- & & --- \\
\hline Loperamide & $2 \mathrm{mg}$ q.i.d. & & Toxic megacolon \\
\hline \multicolumn{3}{|l|}{ Anion exchange resin } & \\
\hline Cholestyramine & $4 \mathrm{~g} 1-6$ times/day & & --- \\
\hline \multicolumn{3}{|l|}{ Long acting somatostatin } & \\
\hline Octreotide acetate & $50 \mu \mathrm{g}$ t.i.d. & & Aggravated nutrient malabsorption \\
\hline Metronidazole & 250 mg t.i.d. & & Fungal overgrowth \\
\hline \multicolumn{3}{|l|}{ a2-receptor agonist } & \\
\hline Clonidine. $\mathrm{HCl}$ & $0.1 \mathrm{mg}$ t.i.d. & & Orthostatic hypotension \\
\hline \multicolumn{3}{|l|}{ Gastrokinetics and anticholinergics } & \\
\hline Aclatonium napadisilate & & & \\
\hline
\end{tabular}




\begin{tabular}{|c|c|c|c|}
\hline \multicolumn{2}{|l|}{ Trimebutine maleate } & & \\
\hline \multicolumn{4}{|l|}{ Tiquizium bromide } \\
\hline \multicolumn{4}{|l|}{ Cispride } \\
\hline \multicolumn{4}{|l|}{ Macrolides } \\
\hline EM523L & $i / v$ infusion & & \\
\hline \multicolumn{4}{|l|}{ Cystopathy } \\
\hline Bethanechol & $10 \mathrm{mg}$ q.i.d. & \multirow[t]{2}{*}{$\begin{array}{l}\text { Cystometrogram } \\
\text { Postvoiding sonography }\end{array}$} & $\begin{array}{l}\text { Salivation, blurred vision, abdominal } \\
\text { cramps, bladder spasm }\end{array}$ \\
\hline Doxazosin & $1-2 \mathrm{mg}$ t.i.d. & & Hypotension, headache, palpitations \\
\hline \multicolumn{4}{|l|}{ Erectile Dysfunction } \\
\hline Sildenafil & $\begin{array}{l}50 \mathrm{mg} \text { o.d., } 1 \mathrm{hr} \text {. before } \\
\text { sexual activity }\end{array}$ & \multirow{3}{*}{$\begin{array}{l}\text { Ultrasound } \\
\text { Urinalysis } \\
\text { Blood test to check testosterone level } \\
\text { Overnight erection test }\end{array}$} & \multirow[t]{3}{*}{$\begin{array}{l}\text { Headache, flushing, nasal congestion, } \\
\text { dyspepsia, muscular skeletal pain, blurred } \\
\text { vision }\end{array}$} \\
\hline Vardenafil & $\begin{array}{l}\text { Up to } 20 \mathrm{mg} / \text { day, } 1 \mathrm{hr} \text {. } \\
\text { before sexual activity }\end{array}$ & & \\
\hline Tadalofil & $\begin{array}{l}\text { Up to } 10 \mathrm{mg} / \text { day, } 1 \mathrm{hr} \text {. } \\
\text { before sexual activity }\end{array}$ & & \\
\hline
\end{tabular}

Table 2: Diagnosis and treatment of diabetic autonomic neuropathy

The cholinesterase inhibitor pyridostigmine improved ganglionic transmission and vascular adrenergic tone in primarily upright position, mediating a slight increase in diastolic blood pressure during standing without worsening supine hypertension [50]. Yohimbine might benefit the patients with noradrenergic innnervation by substantially increasing blood pressure [51]. A clinical trial conducted by Kroll et al. reported that Korodin reduced mean arterial pressure in patients with orthostatic hypotension [52].

\section{Diabetic Gastroparesis}

Autonomic neuropathy is a frequent diagnosis for the gastrointestinal symptoms experienced by patients with chronic diabetes. However, neuropathologic evidence to substantiate the diagnosis is limited. Selim et al., hypothesized that quantification of nerves in gastric mucosa would confirm the presence of autonomic neuropathy. They observed that gastric mucosal nerves were abnormal in patients with type 1 diabetes with secondary complications and clinical evidence of gastroparesis. Gastric mucosal biopsy is a safe, practical method for histologic diagnosis of gastric autonomic neuropathy [53]. Initial treatment of diabetic gastroparesis should focus on blood glucose control, which improves gastric motor function. In addition, patients should be advised to eat multiple small meals (4-6 per day) and reduce the fat content in diet [54]. Prokinetic agents used to treat diabetic gastropathy are metoclopramide, domperidone, erythromycin and levosulpiride. These agents with time become less effective but periodic withdrawal restores response [55]. Another drug, sepiapterin accelerated gastric emptying and attenuated reduced gastric nNOSa expression, and dimerization. Thus sepiapterin is a potential therapeutic for attenuation of diabetic gastroparesis [56]. Finally, after failure of conventional measures, the use of gastric neuromodulation is an effective alternative. This technology works by applying electrical stimulation at the gastric antrum, particularly in patients whose gastric symptoms are refractory to other therapies. Its efficacy has been recently reported in different causes of gastroparesis, especially in diabetes [57].

\section{Diabetic Diarrhea}

Occurrence of diarrhea is frequent in DAN patients. Nocturnal diarrhea and fecal incontinence are common. Correcting fluid and electrolyte balance should be the initial therapy for diabetic diarrhea. Antidiarrheal agents (eg. loperamide) can reduce the number of stools, but they may be associated with toxic megacolon and so should be used with extreme care. A broad-spectrum antibiotic such as metronidazole is usually the treatment of choice for bacterial overgrowth. Clonidine may reverse adrenergic nerve dysfunction and improve diarrhea. Diarrhea resistant to treatment with these agents will respond to octreotide [58].

\section{Cystopathy}

In diabetic autonomic neuropathy, the motor function of the bladder is impaired, but damage to the afferent fibers diminishes bladder sensation. The bladder becomes enlarged to more than three times its normal size. Parasympathomimetics such as bethanechol are sometimes helpful, although frequently they do not fully empty the bladder. Extended sphincter relaxation can be achieved with an alpha-1 blocker, such as doxazosin [59].

\section{Erectile dysfunction}

The prevalence of erectile or sexual dysfunction is about $50 \%$ in men with diabetes and about $30 \%$ in women. Initially, the patient should be urged to forego alcoholic drinks and smoking, cease taking medications known to cause erectile dysfunction [55]. Sildenafil (Viagra) may be taken at a dose of $50 \mathrm{mg}$, or lower for patients with renal failure or hepatic dysfunction. It is contraindicated in ischemic heart disease patients and those taking nitrates [60]. 


\section{Herbal approach towards treatment of DAN}

Ruscus aculeatus, a phytotherapeutic agent, possess vasoconstrictive and venotonic properties make it ideally suited to treat the pooling of blood in the limbs, lack of venous tone and lack of neurally mediated vasoconstriction which frequently characterize orthostatic hypotension. Study suggested that, Ruscus aculeatus is an alphaadrenergic agonist that causes venous constriction by directly activating postjunctional alpha1- and alpha2-receptors and stimulating the release of noradrenaline at the level of the vascular wall. It also possesses venotonic properties: it reduces venous capacity and pooling of blood in the legs and exerts protective effects on capillaries, the vascular endothelium, and smooth muscle. Its flavonoid content strengthens blood vessels, reduces capillary fragility, and helps maintain healthy circulation [61]. Licorice causes volume expansion due to its mineralocorticoid-like effect. This effect of licorice is due to the presence of glycyrrhizic acid and is thus useful in the amelioration of postural hypotension in patients with diabetic autonomic neuropathy [62]. Bark oil of Cinnamomum zeylenicum was found to accelerate the gastric emptying and intestinal transit in the diabetic rats. This oil activates the NO-cGMP pathway and most effective dose was found to be $400 \mathrm{mg} / \mathrm{kg}$. Thus, bark oil of Cinnamomum zeylenicum may become a new choice for patients with diabetic gastroparesis [63].

\section{Conclusion}

Management of DAN is complicated due to involvement of multiple pathogenetic mechanisms. The optimal control and maintenance of normal sugar level and blood pressure are obligatory to prevent the progression of DAN. A few therapeutic agents are employed to treat this insidious disorder. However, further clinical studies are needed to illuminate their therapeutic potential in treating diabetic patients with neuropathy. This leads to more profound need to carry out preclinical studies before going to human clinical trials. Characteristics features and pathological changes occurring during the course of disease in small animals are similar to that of human beings. NOD mouse seems particularly analogous to human type 1 diabetes whereas in type 2 diabetes, GK and ZDF rats' suits better for the experimental studies of DAN. BB/Wor-rats and BBZDR/Wor-rats are outbreed from same BB background, provides unique comparison models representing these two types of diabetes. Choice of animal model for DAN is thus multifactorial. Treating DAN is challenging for both patients and clinicians. Developing a treatment strategy by incorporating the available literature on efficacy, dosing, side effects, contraindications, drug interactions and cost is necessary to develop a tailored treatment for individual patients. Moreover, there is a need to carry out extensive research on the use of medicinal plants in amelioration of DAN, since they can be sourced easily and can be selected on the basis of their anti-diabetic potency. Although several therapeutic agents have been introduced in clinical practice but the pharmacological treatment of DAN remains a challenge for clinicians. In future, novel therapeutic agents working at the level of mitochondrial metabolic control are likely to further improve the management of DAN.

\section{References}

1. Vinik AI, Park TS, Stansberry KB, Pittenger GL (2000) Diabetic neuropathies. Diabetologia 43: 957-973.

2. Edwards JL, Vincent AM, Cheng HT, Feldman EL (2008) Diabetic neuropathy: mechanisms to management. Pharmacol Ther 120: 1-34.
3. Singh R, Kishore L2, Kaur N2 (2014) Diabetic peripheral neuropathy: current perspective and future directions. Pharmacol Res 80: 21-35.

4. Cameron NE, Cotter MA (1997) Metabolic and vascular factors in the pathogenesis of diabetic neuropathy. Diabetes 46 Suppl 2: S31-37.

5. Dyck PJ (1989) Hypoxic neuropathy: does hypoxia play a role in diabetic neuropathy? The 1988 Robert Wartenberg lecture. Neurology 39: 111-118.

6. Cameron NE, Cotter MA (2002) Effects of protein kinase Cbeta inhibition on neurovascular dysfunction in diabetic rats: interaction with oxidative stress and essential fatty acid dysmetabolism. Diabetes Metab Res Rev 18: 315-323.

7. Ishii H, Koya D, King GL (1998) Protein kinase C activation and its role in the development of vascular complications in diabetes mellitus. J Mol Med (Berl) 76: 21-31.

8. Hatfield J (2005) Advanced glycation end-products (AGEs) in hyperglycemic patients. J Young Invest 13: 1.

9. Goh SY, Cooper ME (2008) Clinical review: The role of advanced glycation end products in progression and complications of diabetes. J Clin Endocrinol Metab 93: 1143-1152.

10. Valko M, Leibfritz D, Moncol J, Cronin MT, Mazur M, et al. (2007) Free radicals and antioxidants in normal physiological functions and human disease. Int J Biochem Cell Biol 39: 44-84.

11. Johansen JS, Harris AK, Rychly DJ, Ergul A (2005) Oxidative stress and the use of antioxidants in diabetes: linking basic science to clinical practice. Cardiovasc Diabetol 4: 5.

12. Leinninger GM, Edwards JL, Lipshaw MJ, Feldman EL (2006) Mechanisms of disease: mitochondria as new therapeutic targets in diabetic neuropathy. Nat Clin Pract Neurol 2: 620-628.

13. Baydas G, Nedzvetskii VS, Nerush PA, Kirichenko SV, Yoldas T (2003) Altered expression of NCAM in hippocampus and cortex may underlie memory and learning deficits in rats with streptozotocin-induced diabetes mellitus. Life Sci 73: 1907-1916.

14. Freeman R (2005) Autonomic peripheral neuropathy. Lancet 365: 1259-1270.

15. Rees DA, Alcolado JC (2005) Animal models of diabetes mellitus. Diabet Med 22: 359-370.

16. King AJ (2012) The use of animal models in diabetes research. Br J Pharmacol 166: 877-894.

17. Calcutt NA1, Freshwater JD, Mizisin AP (2004) Prevention of sensory disorders in diabetic Sprague-Dawley rats by aldose reductase inhibition or treatment with ciliary neurotrophic factor. Diabetologia 47: 718-724.

18. Li F1, Szabó C, Pacher P, Southan GJ, Abatan OI, et al. (2004) Evaluation of orally active poly(ADP-ribose) polymerase inhibitor in streptozotocindiabetic rat model of early peripheral neuropathy. Diabetologia 47: 710-717.

19. Muller KA, Ryals JM, Feldman EL, Wright DE (2008) Abnormal muscle spindle innervation and large-fiber neuropathy in diabetic mice. Diabetes 57: 1693-1701.

20. Christianson JA, Ryals JM, McCarson KE, Wright DE (2003) Beneficial actions of neurotrophin treatment on diabetes-induced hypoalgesia in mice. J Pain 4: 493-504.

21. Demiot C, Tartas M, Fromy B, Abraham P, Saumet JL et al. (2006) Aldose reductase pathway inhibition improved vascular and C-fiber functions, allowing for pressure-induced vasodilation restoration during severe diabetic neuropathy. Diabetes 55: 1478-1483.

22. Maeda M, Yabuki A, Suzuki S, Matsumoto M, Taniguchi K, et al. (2003) Renal lesions in spontaneous insulindependent diabetes mellitus in the nonobese diabetic mouse: Acute phase of diabetes. Vet Pathol 40: 187195.

23. Wilson KH, Eckenrode SE, Li QZ, Ruan QG, Yang P, et al. (2003) Microarray analysis of gene expression in the kidneys of new- and postonset diabetic NOD mice. Diabetes 52: 2151-2159.

24. Adorini L, Gregori S, Harrison LC (2002) Understanding autoimmune diabetes: insights from mouse models. Trends Mol Med 8: 31-38. 
25. Baxter AG, Duckworth RC (2004) Models of type 1 (autoimmune) diabetes. Drug Discovery Today 4: 451-455.

26. Pieper GM, Mizoguchi H, Ohsawa M, Kamei J, Nagase H, et al. (2000) Decreased opioid-induced antinociception but unaltered G-protein activation in the genetic-diabetic NOD mouse. Eur J Pharmacol 401: 375-379.

27. Obrosova IG1, Mabley JG, Zsengellér Z, Charniauskaya T, Abatan OI, et al. (2005) Role for nitrosative stress in diabetic neuropathy: evidence from studies with a peroxynitrite decomposition catalyst. FASEB J 19 401-403.

28. Gabra BH, Sirois P (2005) Hyperalgesia in non-obese diabetic (NOD) mice: a role for the inducible bradykinin B1 receptor. Eur J Pharmacol 514: 61-67.

29. Mordes JP, Bortell R, Blankenhorn EP, Rossini AA, Greiner DL (2004) Rat models of type 1 diabetes: genetics, environment, and autoimmunity. ILAR J 45: 278-291.

30. Greiner DL, Rossini AA, Mordes JP (2001) Translating data from animal models into methods for preventing human autoimmune diabetes mellitus: caveat emptor and primum non nocere. Clin Immunol 100: 134-143.

31. Sima AA, Kamiya H (2006) Diabetic neuropathy differs in type 1 and type 2 diabetes. Ann N Y Acad Sci 1084: 235-249.

32. Schmidt RE, Dorsey DA, Beaudet LN, Parvin CA, Zhang W, et al. (2004) Experimental rat models of types 1 and 2 diabetes differ in sympathetic neuroaxonal dystrophy. J Neuropathol Exp Neurol 63: 450-460.

33. Ostenson CG, Efendic S (2007) Islet gene expression and function in type 2 diabetes; studies in the Goto-Kakizaki rat and humans. Diabetes Obes Metab 9 Suppl 2: 180-186.

34. Portha B, Lacraz G, Kergoat M, Homo-Delarche F, Giroix MH, et al. (2009) The GK rat beta-cell: a prototype for the diseased human beta-cell in type 2 diabetes? Mol Cell Endocrinol 297: 73-85.

35. Ueta K, Ishihara T, Matsumoto Y, Oku A, Nawano M, et al. (2005) Longterm treatment with the Na+-glucose cotransporter inhibitor T-1095 causes sustained improvement in hyperglycemia and prevents diabetic neuropathy in Goto-Kakizaki Rats. Life Sci 76: 2655-2668.

36. Kose H, Moralejo DH, Ogino T, Mizuno A, Yamada T, et al. (2002) Examination of OLETF-derived non-insulin-dependent diabetes mellitus QTL by construction of a series of congenic rats. Mamm Genome 13: 558-562.

37. Moralejo DH, Ogino T, Zhu M, Toide K, Wei S, et al. (1998) A major quantitative trait locus co-localizing with cholecystokinin type A receptor gene influences poor pancreatic proliferation in a spontaneously diabetogenic rat. Mamm Genome 9: 794-798.

38. Kamenov Z, Higashino H, Todorova M, Kajimoto N, Suzuki A (2006) Physiological characteristics of diabetic neuropathy in sucrose-fed Otsuka Long-Evans Tokushima fatty rats. Methods Find Exp Clin Pharmacol 28: 13-18.

39. Phillips MS, Liu Q, Hammond HA, Dugan V, Hey PJ, et al. (1996) Leptin receptor missense mutation in the fatty Zucker rat. Nat Genet 13: 18-19.

40. Li F, Abatan OI, Kim H, Burnett D, Larkin D, et al. (2006) Taurine reverses neurological and neurovascular deficits in Zucker diabetic fatty rats. Neurobiol Dis 22: 669-676.

41. Oltman CL, Coppey LJ, Gellett JS, Davidson EP, Lund DD, et al. (2005) Progression of vascular and neural dysfunction in sciatic nerves of Zucker diabetic fatty and Zucker rats. Am J Physiol Endocrinol Metab 289: E113-122.

42. Drel VR, Mashtalir N, Ilnytska O, Shin J, Li F, et al. (2006) The leptindeficient $(\mathrm{ob} / \mathrm{ob})$ mouse: a new animal model of peripheral neuropathy of type 2 diabetes and obesity. Diabetes 55: 3335-3343.

43. Gibran NS, Jang YC, Isik FF, Greenhalgh DG, Muffley LA, et al. (2002) Diminished neuropeptide levels contribute to the impaired cutaneous healing response associated with diabetes mellitus. J Surg Res 108: 122-128.
44. Low PA, Walsh JC, Huang CY, McLeod JG (1975) The sympathetic nervous system in diabetic neuropathy. A clinical and pathological study. Brain 98: 341-356.

45. Freeman R (1999) Cardiovascular autonomic neuropathy. In Diabetic Neuropathy. 2nd ed. Dyck PJ, Thomas PK, Eds. Philadelphia, WB Saunders, p. 541-554.

46. Marfella R, Giugliano D, Cozzolino D, Di Maro G, Giunta R, et al. (1994) Plasma endothelin in diabetic autonomic neuropathy. Diabetes Care 17: 161-162.

47. Schoffer KL, Henderson RD, O'Maley K, O'Sullivan JD (2007) Nonpharmacological treatment, fludrocortisone, and domperidone for orthostatic hypotension in Parkinson's disease. Mov Disord 22: 1543-1549.

48. Figueroa JJ, Basford JR, Low PA (2010) Preventing and treating orthostatic hypotension: As easy as A, B, C. Cleve Clin J Med 77: 298-306.

49. Mäkimattila S, Mäntysaari M, Schlenzka A, Summanen P, Yki-Järvinen $\mathrm{H}$ (1998) Mechanisms of altered hemodynamic and metabolic responses to insulin in patients with insulin-dependent diabetes mellitus and autonomic dysfunction. J Clin Endocrinol Metab 83: 468-475.

50. Singer W, Sandroni P, Opfer-Gehrking TL, Suarez GA, Klein CM, et al. (2006) Pyridostigmine treatment trial in neurogenic orthostatic hypotension. Arch Neurol 63: 513-518.

51. Sharabi Y, Eldadah B, Li ST, Dendi R, Pechnik S, et al. (2006) Neuropharmacologic distinction of neurogenic orthostatic hypotension syndromes. Clin Neuropharmacol 29: 97-105.

52. Kroll M, Ring C, Gaus W, Hempel B (2005) A randomized trial of Korodin Herz-Kreislauf-Tropfen as add-on treatment in older patients with orthostatic hypotension. Phytomedicine 12: 395-402.

53. Selim MM, Wendelschafer-Crabb G, Redmon JB, Khoruts A, Hodges JS, et al. (2010) Gastric mucosal nerve density: a biomarker for diabetic autonomic neuropathy? Neurology 75: 973-981.

54. Valdovinos MA, Camilleri M, Zimmerman BR (1993) Chronic diarrhea in diabetes mellitus: mechanisms and an approach to diagnosis and treatment. Mayo Clin Proc 68: 691-702.

55. Vinik AI, Maser RE, Mitchell BD, Freeman R (1999) Gastrointestinal, genito-urinary, and neurovascular disturbances in diabetes. Diabetes Rev 7: $358-378$.

56. Gangula PR, Mukhopadhyay S, Pasricha PJ, Ravella K (2010) Sepiapterin reverses the changes in gastric nNOS dimerization and function in diabetic gastroparesis. Neurogastroenterol Motil 22: 1325-1331, e351-2.

57. Guerci B, Bourgeois C, Bresler L, Scherrer ML, Böhme P (2012) Gastric electrical stimulation for the treatment of diabetic gastroparesis. Diabetes Metab 38: 393-402.

58. Vinik AI, Erbas T (2001) Recognizing and treating diabetic autonomic neuropathy. Cleve Clin J Med 68: 928-930, 932, 934-44.

59. Joshi N, Caputo GM, Weitekamp MR, Karchmer AW (1999) Infections in patients with diabetes mellitus. N Engl J Med 341: 1906-1912.

60. Rendell MS, Rajfer J, Wicker PA, Smith MD (1999) Sildenafil for treatment of erectile dysfunction in men with diabetes: a randomized controlled trial. Sildenafil Diabetes Study Group. JAMA 281: 421-426.

61. Redman DA (2000) Ruscus aculeatus (butcher's broom) as a potential treatment for orthostatic hypotension, with a case report. J Altern Complement Med 6: 539-549.

62. Shipra Soni, Narendra Silawat (2012) Effect of Cinnamomum Zeylenicum Nees Bark Oil on Drug Induced Diabetic Gastroparesis in Rats. Asian Journal of Biomedical and Pharmaceutical Sciences 2: 15-19.

63. Basso A, Dalla Paola L, Erle G, Boscaro M, Armanini D (1994) Licorice ameliorates postural hypotension caused by diabetic autonomic neuropathy. Diabetes Care 17: 1356. 